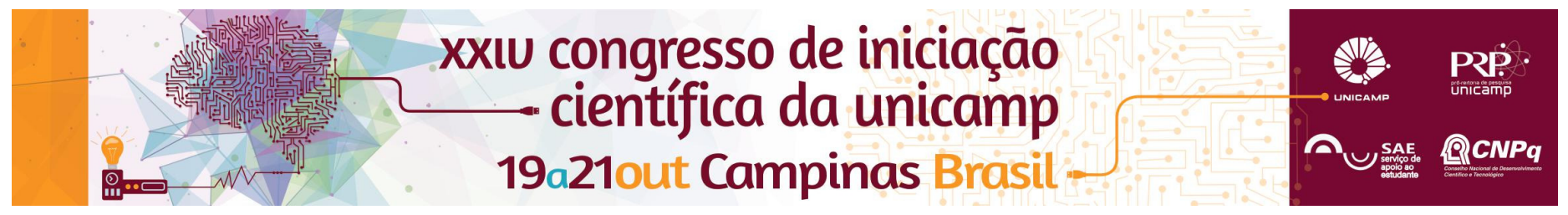

\title{
Direitos Fundamentais e Movimento de Moradia: o caso das ocupações na cidade de São Paulo (2005 - 2015).
}

\author{
Prof. Dr. Frederico Normanha Ribeiro de Almeida, Beatriz Ferruzzi Sacchetin*.
}

\begin{abstract}
Resumo
A pesquisa buscou compreender a questão da legalidade e da legitimidade dos movimentos sociais de moradia e sua relação com a garantia dos direitos fundamentais, baseadas nos princípios fundamentais constitucionais da dignidade humana e da função social da propriedade. Assim, o principal objetivo da investigação foi compreender se, apesar da existência de princípios legais que defendam essas ações, as sentenças judiciais os levaram em conta, preocupandose com a demanda de tais movimentos. $O$ trabalho foi feito a partir da investigação dos processos de reintegração de posse sobre os imóveis ocupados pelos movimentos de moradia, em análise mais específica a respeito das ocupações na cidade de São Paulo, de 2005 a 2015.
\end{abstract}

\section{Palavras-chave:}

Direitos fundamentais, movimento de moradia, Judiciário.

\section{Introdução}

Após a redemocratização e após a promulgação da Constituição Federal de 1988, houve uma mudança na dinâmica de interação entre os atores políticos existentes no cenário nacional, provocando um aumento na mobilização do Poder Judiciário, e não apenas do Legislativo e/ou Executivo. Houve um processo de superação da concepção de que o Poder Judiciário é mero aplicador das normas ditadas pelo Legislativo, e, como consequência, os próprios movimentos sociais tiveram sua estrutura organizacional alterada: passaram a se apropriar da linguagem do Direito, designando membros com legitimidade para defendê-los e se inteirando a respeito da lógica de funcionamento do âmbito jurídico.

Deste modo, a pesquisa analisou a relação existente entre os movimentos sociais de moradia e a garantia do direito de moradia como um direito fundamental a partir de ações do Poder Judiciário.

O objetivo da pesquisa foi, justamente, compreender a maneira com que o poder judiciário interpreta as ações do movimento de moradia. Por mais que o direito à moradia seja expressamente garantido por lei, não necessariamente os repertórios utilizados pelos movimentos são legais, o que nos faz questionar a respeito do tratamento dado a essas ações e repertórios.

\section{Resultados e Discussão}

A pesquisa foi desenvolvida através de análise bibliográfica, de análise da legislação referente ao tema e de análise de dados dos processos de reintegração de posse em que movimentos sociais foram réus.

Em relação à análise bibliográfica, os argumentos trazidos pelos autores consultados giram em torno da ideia de que há uma influência recíproca entre Poder Judiciário e movimentos sociais. Deste modo, essa dinâmica passa a ter efeito importante sobre formação da identidade coletiva dos próprios movimentos e da construção de suas demandas. Isso significa que 0 Direito tem influência na redefinição dos conflitos sociais e também na busca de soluções políticas práticas. Assim, é evidente a importância da análise da percepção do Poder Judiciário sobre as ações dos movimentos sociais, pois se torna possível a compreensão com mais profundidade da dinâmica política de interação dos movimentos sociais com o direito e como isso afeta suas pautas e seus repertórios.

DOI: 10.19146/pibic-2016-50976
A análise da legislação foi baseada na Constituição Federal, no Código Civil, no Código de Processo Civil, no Estatuto da Cidade (Lei n 10257/01) e na Lei Orgânica do Município de São Paulo. Foi, assim, possível perceber que a legislação vigente a respeito de planejamento urbano e políticas públicas de habitação é bastante protecionista e proporciona recursos para que seja possível a efetivação da usucapião especial de imóveis urbanos. E a análise dos processos de reintegração de posse foi feita para verificar se os argumentos trazidos na prática estão de acordo com aqueles da legislação.

Esta última análise, então, foi feita através de dados do portal online do Tribunal de Justiça do Estado de São Paulo (TJSP), selecionando apenas processos em primeira instância e através de palavras-chaves determinadas. Foram encontrados diversos resultados quantitativos relevantes para o entendimento da dinâmica entre Judiciário e movimentos sociais. Foram encontrados 23 movimentos sociais em 57 ações analisadas; verificou-se que das 29 sentenças analisadas, apenas duas foram julgadas improcedentes (movimentos de moradia puderam permanecer nas ocupações); dos requerentes, 23 eram pessoas físicas e 34 pessoas jurídicas; e em relação à data de distribuição, a grande maioria dos processos está concentrada no ano de 2014 (24 processos). Do total de processos, apenas 25 foram encerrados.

\section{Conclusões}

Amparo legal é encontrado tanto para a defesa da propriedade quanto para o direito à moradia. A propriedade é inviolável (salvo em casos específicos), contudo, deve-se obrigatoriamente respeitar o seu uso social.

Entretanto, a partir da análise dos casos concretos de julgamentos dos processos de reintegração de posse, observou-se que a porcentagem de decisões dadas em favor dos movimentos de moradia foi muito desproporcional às decisões dadas em favor dos proprietários dos imóveis (mérito e indenizações).

Assim, as ações de reintegração de posse podem não ser o melhor lugar para a afirmação pela via judicial do direito social à moradia, já que são ações específicas de defesa da propriedade; apesar disso, é sintomático que a grande maioria das ações tenham sido favoráveis aos proprietários, e pouquíssimas tenham permitido a permanência dos movimentos. 